
ISSN : 2615-1995, E-ISSN : 2615-0654

J. Madani., Vol. 3, No. 1, Maret 2020 (1 - 12)

(C)2018 Lembaga Kajian Demokrasi

\title{
Perancangan Sistem Informasi Manajemen Bengkel Berbasis Web (Studi Kasus: Bengkel Anugrah)
}

\author{
Meri Audrilia \\ Fakultas Teknik dan Ilmu Komputer, Universitas Teknokrat Indonesia \\ meriaudrilia@gmail.com \\ Arief Budiman \\ Fakultas Teknik dan Ilmu Komputer, Universitas Teknokrat Indonesia \\ arief.budiman10@teknokrat.ac.id
}

\begin{abstract}
Abstrak
Bengkel Anugrah adalah perusahaan yang bergerak dalam bidang jasa service kendaraan dan penjualan sparepart kendaraan roda empat. Setiap transaksi masih dilakukan secara manual yaitu masih dilakukan dengan ditulis menggunakan buku penjualan, dan belum terdapat laporan penjualan per periode. Sering terjadi kehabisan stok barang dikarnakan tidak adanya informasi jika stok barang habis. Dan pelanggan harus datang langsung untuk melakukan service dan mendapatkan informasi barang yang dijual apakah barang masih tersedia atau tidak. Metode pengembangan sistem menggunakan metode web engineering (Communication, Planning, Modeling, Construction, Deployment) dan perancangan sistem menggunakan UML. Penulis juga menggunakan metode penelitian pengamatan, tinjauan pustaka, dan dokumentasi. Hasil yang dicapai adalah sebuah aplikasi berbasis web manajemen bengkel pada Bengkel Anugrah. Aplikasi ini dibuat menggunakan dreamweaver dan mysql sebagai database, sistem yang dibangun dapat menhasilkan laporan penjualan. Hasil pengujian ISO 25010 yang telah diilakukan dengan melibatkan 7 Responden bahwa kesimpulan kualitas kelayakan perangkat lunak yang dihasilkan secara keseluruhan dengan persentase 92,38\%.
\end{abstract}

Kata Kunci : Sistem Informasi Manajemen, Bengkel, Web Engineering, UML

\begin{abstract}
Anugrah Workshop is a company engaged in the field of vehicle service and sales of four-wheeled vehicle spare parts. Every transaction is still done manually, that is still done by writing using a sales book, and there are no sales reports per period. There is often an out of stock of goods due to lack of information if the stock is out of stock. And customers must come directly to do service and get information on goods sold whether the goods are still available or not. The system development method uses web engineering methods (Communication, Planning, Modeling, Construction, Deployment) and system design using UML. The author also uses observational research methods, literature reviews and documentation. The result achieved is a web-based workshop management application at Anugrah Workshop. This application was created using Dreamweaver and MySQL as a database, the system built can generate sales reports. ISO 25010 test results that have been carried out by involving 7 Respondents that the conclusion of the quality of the feasibility of the overall software produced with a percentage of $92.38 \%$.
\end{abstract}

Keywords : Management Information Systems, Workshop, Web Engineering, UML 


\section{PENDAHULUAN}

Kemajuan di bidang teknologi, komputer, dan telekomunikasi mendukung perkembangan teknologi internet. Dengan internet pelaku bisnis tidak lagi mengalami kesulitan dalam memperoleh informasi apapun, untuk menunjang aktivitas bisnisnya, bahkan sekarang cenderung dapat diperoleh berbagai macam informasi, sehingga informasi harus disaring untuk mendapatkan informasi yang tepat dan relevan. Hal tersebut mengubah abad informasi menjadi abad internet (Yuliana, 2000).

Tidak jarang juga perkembangan teknologi dan informasi telah merambah ke berbagai bidang diantaranya bidang industri, pendidikan, dan lain sebagainya. Dalam bidang industri ada beberapa bisnis yang masih menggunakan cara lama dalam proses bisnisnya, cara lama tersebut adalah dalam melakukan proses transaksi masih menggunakan catat mencatat, salah satunya yang masih banyak menggunakan cara lama tersebut adalah dalam bisnis bengkel. Dengan perkembangan teknologi informasi saat ini, pengelolaan proses transaksi di bengkel dapat dilakukan secara lebih optimal bila memanfaatkan teknologi informasi. Penggunaan teknologi informasi bertujuan untuk mempermudah dalam pengelolaan informasi dan keakuratan informasi (Setiadi \& Setiawan, 2016).

Bengkel Anugrah adalah perusahan yang bergerak dalam bidang jasa service kendaraan dan penjualan sparepart kendaraan roda empat. Berdasarkan hasil wawancara yang dilakukan kepada pemilik bengkel dan observasi yang dilakukan penulis, proses sistem berjalan pada Bengkel Anugrah dimulai dari pelanggan melakukan service kendaraan dan selanjutnya dikelola data penjualan sparepart sesuai service yang dilakukan, dalam proses pengelolaan data bengkel seperti data service dan penjualan, bengkel ini belum menerapkan sistem secara terkomputerisasi. Setiap transaksi masih dilakukan secara manual yaitu masih dilakukan dengan ditulis menggunakan buku penjualan, dan belum terdapat laporan penjualan per periode. Sering terjadi kehabisan stok barang dikarenakan tidak adanya informasi jika stok barang habis selain itu pelanggan harus datang langsung untuk me- lakukan service dan mendapatkan informasi barang yang dijual apakah barang masih tersedia atau tidak.

Solusi dari masalah pada bengkel Anugrah maka akan dibangun sistem informasi manajemen bengkel berbasis web yang dapat memberikan kemudahan bagi pelanggan dalam mencari informasi sparepart yang tersedia dan informasi data service. Dengan adanya sistem ini bertujuan memfasilitasi proses transaksi bengkel agar lebih mudah. Menyediakan informasi yang lengkap mengenai informasi sparepart dan informasi data service yang dibutuhkan pelanggan dan sistem ini juga akan menyediakan fitur booking service agar memudahkan pelanggan dalam melakukan pesanan service serta web ini juga akan menyediakan laporan penjualan untuk memudahkan pihak bengkel dalam melihat laporan penjualannya.

\section{Batasan Masalah}

Berdasarkan latar belakang masalah yang telah dipaparkan, maka batasan masalah dalam penelitian ini adalah sebagai berikut: Pelanggan harus datang ke bengkel untuk melakukan transaksi pembelian.Pelanggan hanya dapat melihat informasi sparepart dan informasi data saat service pada sistem. Pengembangan sistem menggunakan web engineering dan perancangan menggunakan UM. Hanya membahas data sparepart, data penjualan, data service, dan outputan sistem yaitu laporan penjualan, laporan data service dan grafik.

\section{METODE}

\section{Tahapan Penelitian}

Tahapan penelitian dalam sistem informasi bengkel dapat dilihat pada Gambar 1.

\section{Analisis Modelling}

1. Sistem mampu menambahkan dan menampilkan data pemesanan secara keseluruhan atau pencarian data satu persatu.

2. Sistem mampu menambahkan dan menampilkan data booking keseluruhan atau pencarian data satu persatu.

3. Sistem mampu menambahkan user baru. 


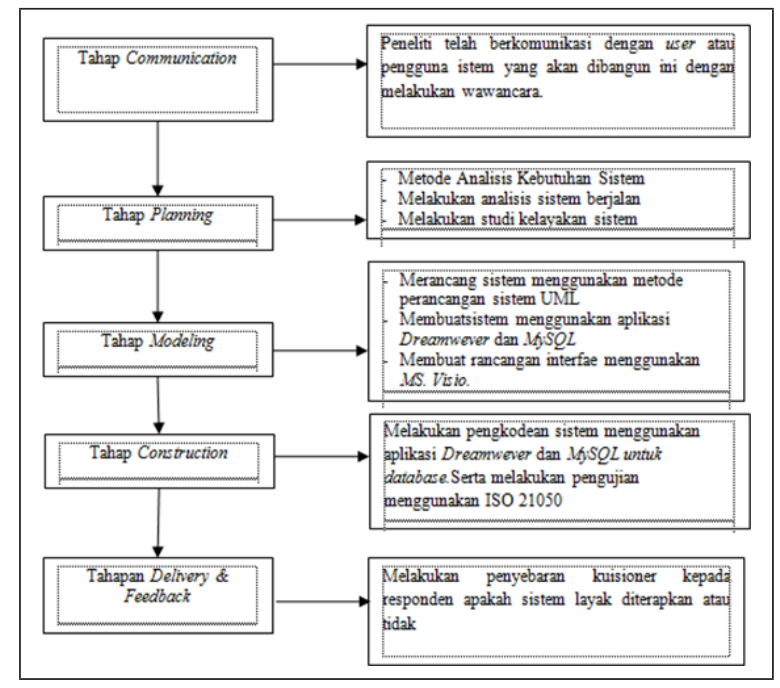

Gambar 1. Tahapan Penelitian

4. Sistem mampu menambahkan dan menampilkan laporan.

5. Sistem mampu mencetak laporan.

6. Sistem dapat menampilkan grafik.

\section{Use Case Diagram}

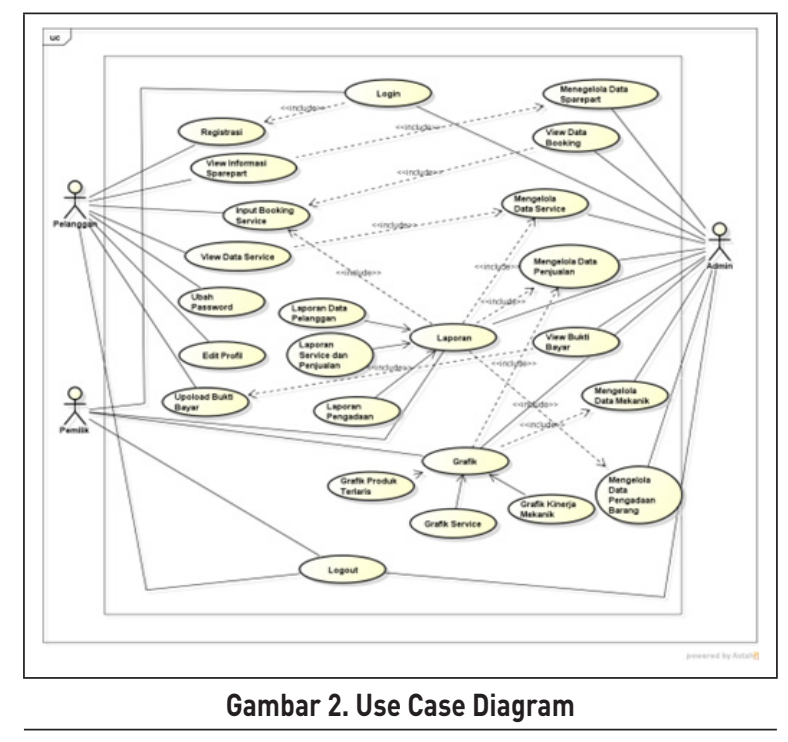

\section{Metode Pengumpulan Data}

Metode pengumpulan data dilakukan untuk memperoleh informasi tentang penelitian yang akan dilakukan. Adapun metode pengumpulan data yang digunakan dalam penelitian ini yaitu:

\section{Studi literatur}

Pada tahap ini dilakukan kajian literatur dari buku, jurnal, dan internet yang mengulas tentang penjualan, laporan penjualan, dan inventory penjualan.

\section{Wawancara}

Pengumpulan data dengan metode wawancara yaitu metode pengumpulan data dengan cara tanya jawab secara langsung kepada pemilik Bengkel. Melakukan pertanyaan seputar sistem yang berjalan mengenai proses service yang dilakukan dan transaksi penjualan sparepart yang dilakukan pada Bengkel Anugrah.

\section{Pengamatan (Observastion)}

Pengumpulan data dengan mengamati atau observation yaitu metode pengumpulan data dengan cara mengamati langsung kegiatan yang terjadi pada bengkel Anugrah dan mempelajari segala sesuatu yang berhubungan dengan sistem yang akan dibangun.

\section{Dokumentasi}

Dokumentasi adalah instrument yang juga sangatlah dibutuhkan dalam pengumpulan data. Dokumentasi dilakukan untuk mendapatkan data yang sesuai atau valid mengenai informasi yang dibutuhkan, yaitu dengan mendokumentasikan data-data yang dibutuhkan dalam penelitian.

\section{HASIL dan PEMBAHASAN \\ Tinjauan Pustaka}

Beberapa penelitian yang pernah dilakukan terkait dengan penelitian yang dilakukan dapat dilihat pada Tabel 1.

\begin{tabular}{|c|c|c|c|}
\hline \multicolumn{4}{|c|}{ Tabel 1. Tinjauan Pustaka } \\
\hline $\begin{array}{c}\text { No } \\
\text { Literatur }\end{array}$ & Penulis & Tahun & Judul \\
\hline Literatur 1 & $\begin{array}{l}\text { Nur, Hidayat } \\
\text { Muhammad }\end{array}$ & 2016 & $\begin{array}{l}\text { Sistem Informasi Service } \\
\text { dan Penjualan Sparepart } \\
\text { Motor Yamaha Pada } \\
\text { PD Enggal Jaya Motor } \\
\text { cikarang Barat }\end{array}$ \\
\hline Literatur 2 & $\begin{array}{l}\text { Setiadi, Nugraha dan } \\
\text { Setiawan, Ridwan }\end{array}$ & 2016 & $\begin{array}{l}\text { Pengembangan Aplikasi } \\
\text { Penjualan Sparepart Di } \\
\text { Bengkel Anugrah Jaya } \\
\text { Motor Berbasis Desktop }\end{array}$ \\
\hline Literatur 3 & $\begin{array}{l}\text { Welim, Yohanes Yahya., } \\
\text { dkk }\end{array}$ & 2015 & $\begin{array}{l}\text { Pengembangan Sistem } \\
\text { Informasi Service } \\
\text { Kendaraan Pada Bengkel } \\
\text { KFMP }\end{array}$ \\
\hline Literatur 4 & Setiadi, Ade dan Alfiah & 2016 & $\begin{array}{l}\text { Sistem Penjualan } \\
\text { Sparepart Toko Ajm Motor } \\
\text { Menggunakan Ci Berbasis } \\
\text { Arsitektur Mvc }\end{array}$ \\
\hline Literatur 5 & Darwis, Dedi., dkk & 2019 & $\begin{array}{l}\text { Perancangan Sistem } \\
\text { Infirmasi Akuntansi } \\
\text { Pengeluaran Operasional } \\
\text { Perusahaan }\end{array}$ \\
\hline
\end{tabular}




\section{Literatur 1}

Dalam menjalankan usahanya perusahaan tersebut masih menggunakan aplikasi yang bersifat manual seperti Microsoft excel. Tujuan dari penelitian ini yaitu membuat sistem yang dapat meningkatkan kinerja perusahaan, serta mengefisienkan waktu dalam proses pelaporan service dan penjualan sparepart motor di bengkel PD Enggal Jaya Motor. Metode yang digunakan dalam penelitian ini yaitu metode Waterfall. Hasil dari penelitian ini adalah sistem informasi pelayanan service dan penjualan sparepart yang dapat memberikan kemudahan kepada pihak admin dan pimpinan dalam proses transaksi service dan penjualan sparepart dan untuk mengetahui data-data transaksi beserta laporannya.

\section{Literatur 2}

Pada proses transaksi di bengkel ini masih menggunakan buku catatan biasa yang kurang efektif dalam melakukan proses transaksi dan proses pembuatan laporan karena masih dicatat, begitu pula dengan pengecekan jumlah stok barang dimana untuk mengetahui jumlah stok barang dilakukan dengan cara pengecekan satu persatu saat akan melakukakn pemesanan. Tujuan dari penelitian ini adalah membuat aplikasi yang mempermudah proses transaksi, proses pengecekan barang dan pembuatan laporan. Dan hasil dari penelitian ini yaitu perancangan aplikasi dan aplikasi penjualan sparepart berbasis desktop. Penelitian ini berfokus pada proses transaksi penjualan, proses pembuatan laporan dan jumlah stok barang. Aplikasi ini dapat mengakomodir proses pembuatan transaksi dan laporan menjadi lebih cepat dan mudah, proses pengecekan barang secara realtime.

\section{Literatur 3}

Bengkel KFMP adalah ussaha milik perorangan yang bergerak dalam bidang jasa yaitu perbaikan mobil khususnya spesialis untuk mobilmobil produksi dari Honda atau mobil buatan Jepang seperti CRV. Untuk setiap perbaikan kendaraan tersebut harus melakukan pencatatan dan perhitungan administrasi service. Proses penyelesaian transaksi tersebut sampai sekarang masih menggunakan sistem manual, mulai dari proses pendaftaran pelangan maupun pendaaan tanda pembayaran serta pembuatan laporan yang ditujukan kepada kepala bengkel. Tujuan dari penelitian ini yaitu melakukan pengembangan sistem informasi service kendaraan untuk menjawab permasalahan yang terjadi saat ini agar pelanggan merasakan pelayanan yang baik. Hasil yang diperoleh dari pengembangan sistem ini adalah dengan melakukan tahapan analisa sistem, analisa-analisa perancangan sistem dan perancangan basis data sehingga mempermudah kegiatan perusahaan, mengolah data, membuat laporan menjadi lebih mudah dan efisien, penyajian informasi yang akurat, relevan dan tepat waktu membuat pihak manajemen dalam mengambil keputusan.

\section{Literatur 4}

Toko AJM Motor bergerak dalam bidang penjualan sparepart mobil dan masih menggunakan cara yang konvensional dalam mengolah data tentang transaksi penjualannya. Dengan dirancangnya sistem ini telah mempermudah pemilik toko dalam mengelola data pelanggan, supplier dan barang yang dibeli dan dijual serta pembuatan lapporan yang diperlukan untuk perhitungan penjualan dan dapat memberikan informasi yang berguna bagi pemilik toko secara up to date.

\section{Literatur 5}

PT Sari Segar Husada adalah perusahaan yang bergerak dalam bidang produksi natadecoco, minyak, dan tepung terigu. Pada saat ini pengolahan data pengularan operasional perusahaan telah dilakukan secara terkomputerisasi yaitu ke dalam spreadsheet. Terdapat kendala yaitu pembuatan file baru setiap bulannya, yang akhirnya menyulitkan dalam pencarian data, dan tidak adanya tempat penyimpanan data yang lebih efisien sehingga mengakibatkan rentan kehilangan data dikarenakan terserang virus, tidak ada informasi jika terjadi kesalahan dalam penginputan, tidak ada laporan per periode. Untuk mengatasi masalah yang berhubungan dengan pengolahan data pengeluaran operasional 
perusahaan, Maka dibutuhkan suatu sistem informasi akuntasi pengeluaran operasional perusahaan. Dengan adanya sistem informasi akuntansi pengeluaran operasional perusahaan akan dapat mengolah data pengeluaran biaya operasional perusahaan dengan baik dan dapat memberikan informasi yang dibutuhkan perusahaan mengenai pengeluaran operasional.

\section{Perancangan}

Perancangan adalah penggambaran, perencanaan, dan pembuatan sketsa atau pengaturan dari beberapa elemen yang terpisah kedalam suatu kesatuan yang utuh dan berfungsi. Dengan demikian pengertian rancang bangun merupakan kegiatan menerjemahkan hasil analisa ke dalam bentuk paket perangkat lunak kemudian menciptakan sistem tersebut atau memperbaiki sistem yang sudah ada (Pressman, 2012).

\section{Sistem}

Kumpulan dari elemen-elemen yang berinteraksi untuk mencapai suatu tujuan tertentu (Jogiyanto, 2005).

\section{Informasi}

Informasi merupakan kumpulan data yang diolah menjadi bentuk yang lebih berguna dan lebih berarti bagi yang menerima. Tanpa suatu informasi, suatu sistem tidak akan berjalan dengan lancar dan akhirnya bisa mati. Suatu organisasi tanpa adanya suatu informasi maka organisasi tersebut tidak bisa berjalan dan tidak bisa beroperasi (Kristanto, 2018).

Informasi adalah data yang diolah menjadi bentuk yang berguna dan menjadi berarti bagi penerimanaya (Sutanta, 2012).

Jadi informasi adalah kumpulan data yang diolah menjadi bentuk yang lebih berguna dan lebih berarti bagi yang menerimanya.

\section{Sistem Informasi}

Sistem informasi merupakan suatu sistem yang dibuat oleh manusia yang terdiri dari komponen-komponen dalam organisasi untuk mencapai suatu tujuan yaitu menyajikan informasi (Kristanto, 2018).
Sistem informasi adalah suatu sistem di dalam suatu organisasi yang mempertemukan kebutuhan pengelolaan transaksi harian yang mendukung fungsi operasi organisasi yang bersifat manajerial dengan kegiatan strategi dari suatu organisasi untuk dapat menyediakan kepada pihak luar tertentu dengan laporan-laporan yang diperlukan (Sutabri, 2012).

Jadi sistem informasi adalah suatu sistem yang dibuat manusia yang terdiri dari komponenkomponen yang mempertemukan kebutuhan pengolahan transaksi harian yang mendukung fungsi operasi organisasi yang bersifat manajerial dan kegiatan strategi untuk dapat menyediakan kepada pihak luar tertentu dengan laporanlaporan yang diperlukan.

\section{Manajemen}

Manajemen adalah usaha untuk mencapai/ menggapai tujuan tertentu melalui kegiatan/ usaha orang lain (McLeod, 2007).

Manajemen adalah seni untuk mencapai tujuan tertentu yang dilakukan oleh orang lain/ usaha orang lain (Pangestu, 2013).

\section{Sistem Informasi Manajemen}

Sistem informasi manajemen (management information system atau sering disebut MIS) merupakan penerapan sistem informasi di dalam organisasi untuk mendukung informasiinformasi yang dibutuhkan oleh semua tingkatan manajemen (Jogiyanto, 2005).

\section{Database}

Database adalah sekumpulan informasi yang diatur agar mudah dicari. Dalam arti umum basis data adalah sekumpulan data yang diproses dengan bantuan komputer yang memungkinkan data dapat diakses dengan mudah dan tepat, yang dapat digambarkan sebagai aktivitas dari satu atau lebih organisasi yang berelasi (Kustiyaningsih, 2011). Berdasarkan pengertian database di atas dibawah ini merupakan jenis database yang digunakan:

\section{- Xampp}

XAMPP adalah sebuah software yang berfungsi untuk menjalankan website berbasis 
PHP dan menggunakan pengolah data MySQL dikomputer lokal. XAMPP berperan sebagai server web pada komputer anda. XAMPP juga dapat disebut sebuah CPanel server virtual, yang dapat membantu anda melakukan preview sehingga dapat memodifikasi website tanpa harus online atau terakses dengan internet (Wicaksono, 2012).

- MySQL

MySQL adalah salah satu data bases management system (DBMS) dari sekian banyak DBMS seperti Oracle, MS SQL, Postagre SQL, dan lainya”. MySQL berfungsi untuk mengolah database menggunakan bahasa SQL. MySQL bersifat open source sehingga kita bisa menggunakannya secara gratis. Pemograman PHP juga sangat mendukung/support dengan database MySQL (Anhar, 2010).

\section{- Perancangan Sistem UML}

\section{(Unified Modeling Language)}

Unified Modeling Language (UML) adalah bahasastandaruntukmenulis perangkatlunak dalam bentuk gambar. UML dapat digunakan untuk memvisualisasikan, menentukan, membangun, dan mendokumentasikan sebuah sistem perangkat lunak (Pressman, 2012).

\section{Metode Pengembangan Sistem}

Tahapan Metode pengembangan sistem yang digunakan dalam penelitian ini adalah web engineering (rekayasa web) yaitu suatu model rekayasa perangkat lunak yang digunakan untuk perkembangan aplikasi-aplikasi berbasis web, sedangkan menurut Pressman (2012) web engineering adalah suatu proses yang digunakan untuk membuat web yang berkualitas tinggi.

Web engineering tidak sama persis dengan RPL (Rekayasa Perangkat Lunak), tetapi rekayasa web memiliki konsep dan prinsip mendasar dari RPL. Proses rekayasa web lebih ditekankan pada aktivitas teknis dan menajemen yang hampir sama (Pressman, 2012). Tahapan rekayasa web dapat dilihat pada Gambar 3.

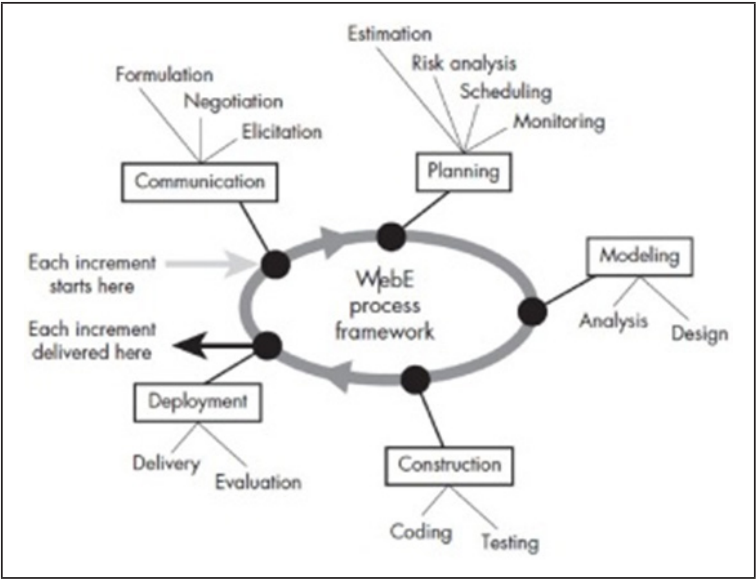

Gambar 3. Tahapan Metode Rekayasa Web

Tahapan-tahapan dalam rekayasa web antara lain:

\section{- Customer communication}

Komunikasi yang baik dengan user merupakan sarana efektif dalam membuat atau menerjemahkan apa saja yang user inginkan (requirements).

Formulation: Melakukan perumusan masalah terhadap sistem yang akan dibangun.

Negatitation: Melakukan perjanjian untuk melakukan pengembangan sistem sesuai kebutuhan.

Elicitation: Melakukan observasi terhadap sistem yang akan dibangun.

\section{- Planning}

Yaitu tahap penggabungan requirement (kebutuhan) dan informasi dari user bisa berupa wawancara dan perencanaan teknis. Perencanaan teknis dilakukan dengan mengidentifikasi perangkat lunak maupun perangkat keras apa saja yang dibutuhkan.

Estimation: Melakukan perkiraan biaya sistem yang akan dibangun.

Risk Analysis: Melakukan analisis resiko yang akan dihadapi oleh pengembang sistem.

Scheduling: Melakukan penjadwalan sistem yang akan diterapkan.

Monitoring: Melakukan pemantauan terhadap sistem yang akan dikembangkan.

\section{Modeling (Pemodelan)}

Analysis modeling, merupakan tahap berikutnya dari planning dan komunikasi dengan user. Yaitu merumuskan kebutuhan 
(requirements) dari user serta permasalahan apa yang akan diselesaikan, mengidentifikasi interaksi antara user dengan sistem berdasarkan hak akses pengguna, juga analisis fungsional yaitu mengidentifikasi operasioperasi apa saja yang akan dijalankan pada sistem sistem.

Design modeling, merupakan desain antarmuka (Interface), merancang tampilan halaman dengan kombinasi warna, teks, dan gambar yang sesuai dengan isi dan tujuan aplikasi web, Desain navigasi sesuai dengan alur kerja sistem, Desain tersebut dirancang berdasarkan kebutuhan informasi yang telah di identifikasi pada tahap analisis.

- Construction (Kontruksi) Implementasi (Coding)

Implementasi dilakukan dengan mengaplikasikan halaman web dalam bentuk HTML berdasarkan hasil perancangan isi pada aktivitas pada non technical member sedangkan implementasi isi dan fungsi logika dibuat dalam bentuk PHP.

\section{- Pengujian (Testing)}

Dilakukan untuk mengetahui kemungkinan terjadinya kesalahan seperti kesalahan pada skrip atau form, navigasi ataupun tampilan, maupun bagian lainnya.

\section{- Deployment}

Serah terima dan respon dilakukan dengan cara menyebarkan kuisioner kepada user berupa respon untuk mendapatkan penilaian dari setiap kriteria sebagai hasil evaluasi bagi pengembang. Kriteria yang dilakukan biasanya usability, functionality, serta reliability.

Delivery: Melakukan pelayanan sesuai sistem yang telah dibangun.

Evaluation: Melakukan penilaian apakah sistem yang dibagun sesuai dengan kebutuhan sistem.

Beberapa tampilan produk aplikasi mengadopsi hasil penelitian yang dilakukan oleh Pasaribu (2019) sebagai referensi dalam mendesain website untuk sistem informasi manajemen bengkel.

\section{Menu Utama}

Menu utama digunakan untuk melihat menu utama awal tampilan program. Tampilan menu utama dapat dilihat pada Gambar 4.

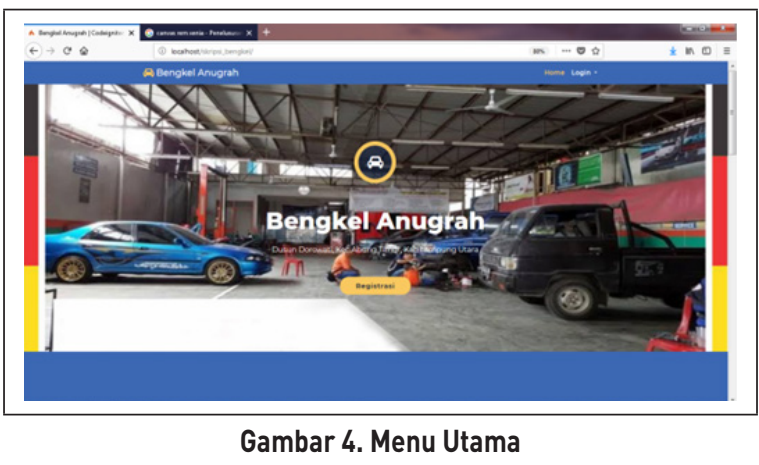

\section{Hak Akses Pelanggan \\ Menu Login}

Tampilan Login Pelanggan digunakan untuk masuk ke dalam sistem, pelanggan yang akan menggunakan sistem sebelumnya harus melakukan registrasi terlebih dahulu pada menu registrasi, lalu memasukkan username dan password yang sesuai pada menu login dan menekan tombol login, sistem akan memproses username dan password tersebut. Bila inputan bernilai benar maka sistem akan mengarahkan ke halaman menu utama, dan apabila salah maka sistem akan memberikan peringatan bahwa username dan password tidak benar.

Tampilan menu login dapat dilihat pada Gambar 5.

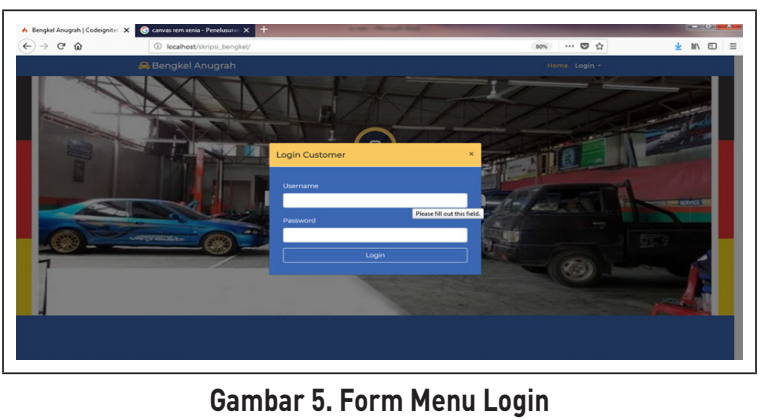

\section{Menu Booking Service}

Tampilan booking service digunakan untuk pelangan yang ingin melakukan pemesanan service, pelanggan wajib menginputkan data booking pada form menu booking service lalu mengklik tombol booking, kemudian akan diproses oleh admin pada tampilan menu view 
booking service pada dashboard admin. Tampilan menu form booking service dapat dilihat pada Gambar 6.

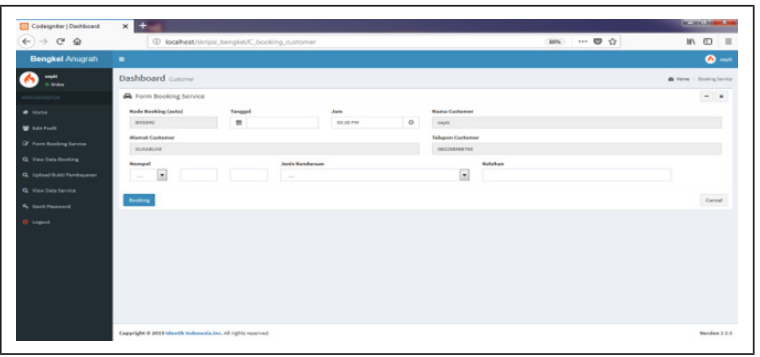

Gambar 6. Form Booking Service

\section{Menu View Data Service}

Menu Service digunakan untuk melihat history data service yang sudah dilakukan oleh pelanggan. Tampilan menu service dapat dilihat pada Gambar 7.

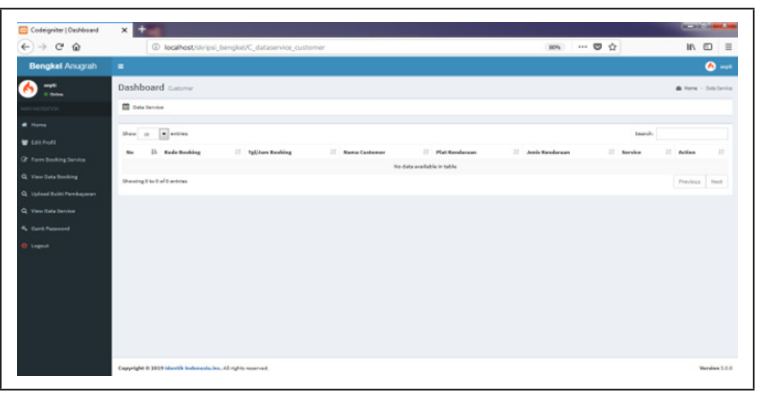

Gambar 7. Form Menu Service

\section{Menu View Data Booking}

Menu view booking digunakan untuk melihat informasi booking, dan pelanggan akan mendapatkan feedback dari admin jika kendaraan sedang diprses atau sudah selesai service. Tampilan pada menu booking dapat dilihat pada Gambar 8.

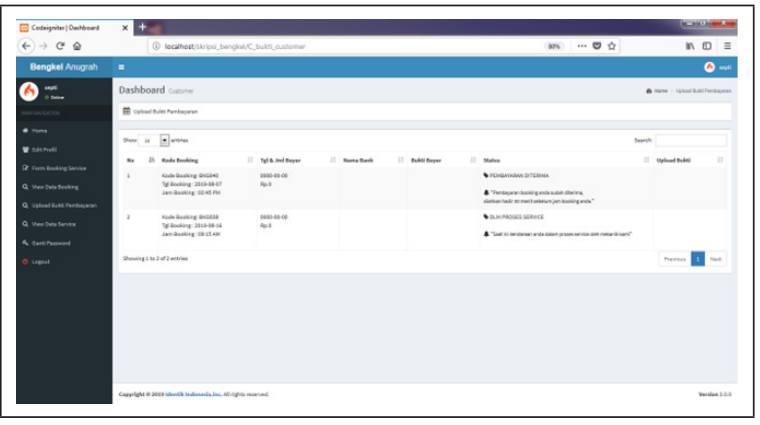

Gambar 8. Form Menu Booking

\section{Hak Akses Admin}

\section{Menu Login Admin}

Admin yang akan menggunakan aplikasi akan memasukkan username dan password yang telah diberikan, lalu menekan tombol login, sistem akan memproses username dan password tersebut. Bila inputan bernilai benar maka sistem akan mengarah ke halaman menu utama dan bila salah maka sistem akan memberikan peringatan bahwa username dan password tidak benar.

Tampilan menu Login dapat dilihat pada Gambar 9.

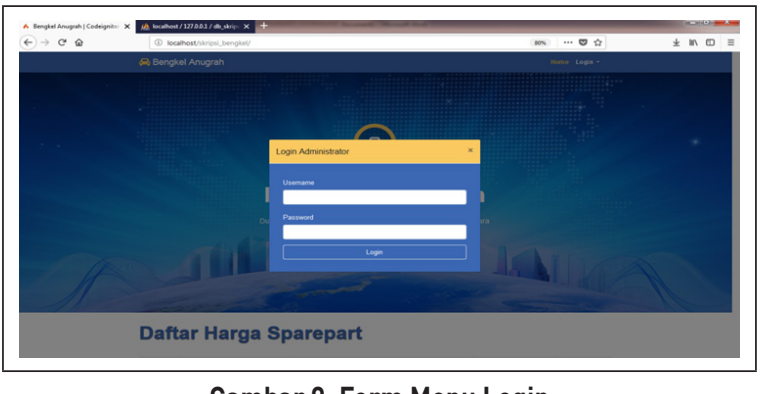

Gambar 9. Form Menu Login

\section{Menu Transkasi Offline}

Tampilan menu transaksi offline digunakan untuk mengelola data penjualan offline, ketika pelanggan langsung datang ke bengkel untuk melakukan pembelian sparepart admin akan menginputkan sparepart yang di beli oleh pelanggan dengan menekan tombol create new dan menekan tombol print faktur untuk mencetak faktur yang akan diberikan oeh pelanggan untuk melakukan pembayaran. Tampilan menu transaksi offline dapat dilihat pada Gambar 10 dan tampilan menu input sparepart dapat dilihat pada Gambar 11.

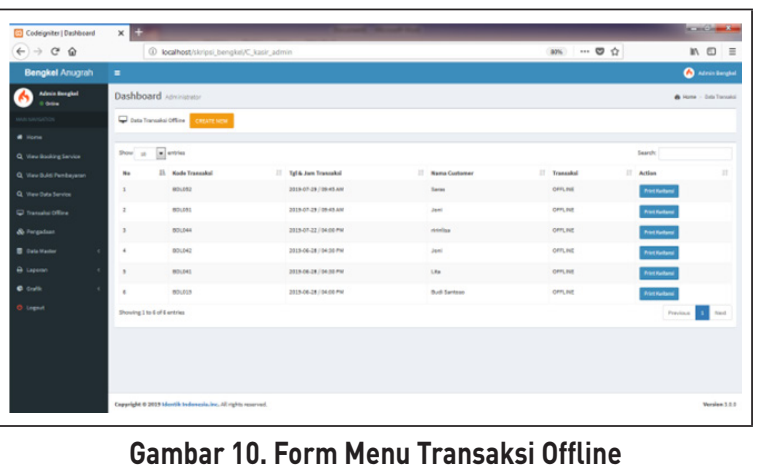




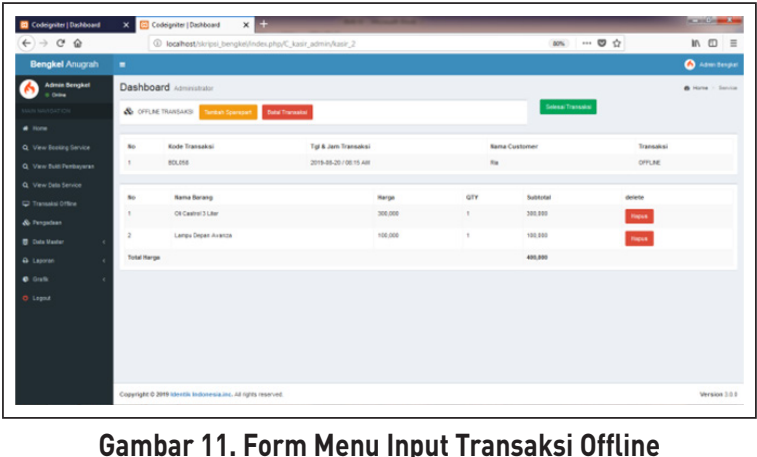

\section{Menu Pengadaan Barang}

Tampilan menu pengadaan barang digunakan untuk mengelola data permintaan sparepart yang dapat diaskes oleh admin. Admin menekan tombol input permintaan untuk menginputkan data permintaan sparepart pada supplier. Tampilan menu sparepart dapat dilihat pada Gambar 12.



Gambar 12. Form Menu Permintaan Sparepart

\section{Menu Data Sparepart}

Tampilan menu data sparepart digunakan untuk mengelola data sparepart yang dapat diakses oleh admin, admin dapat menekan tombol tambah baru untuk menginputkan data barang atau sparepart yang dijual jika sudah selesai dapat menekan tombol simpan data, jika ingin merubah data dapat menekan tombol edit, dan jika ingin menghapus data dapat menekan tombol hapus.



Gambar 13. Form Menu Sparepart
Tampilan menu sparepart dapat dilihat pada Gambar 13 dan tampilan input sparepart dapat dilihat pada Gambar 14.

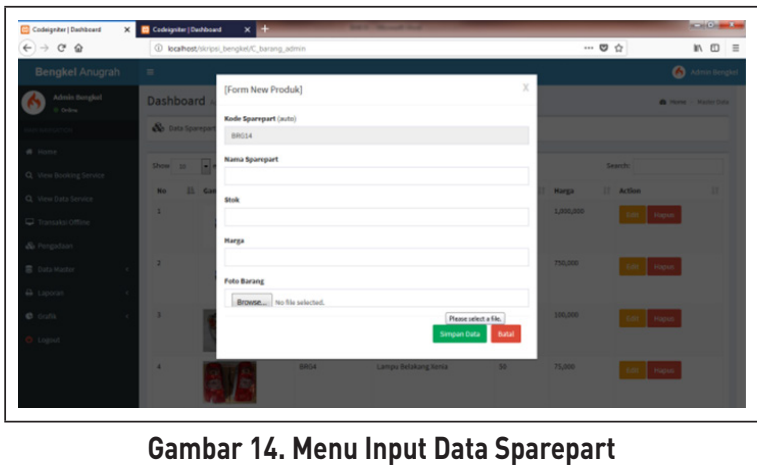

\section{Menu Mekanik}

Tampilan menu mekanik digunakan untuk mengelola data mekanik yang dilakukan oleh admin, untuk menambah data mekanik admin dapat menekan tombol tambah baru dan jika ingin mengubah data mekanik admin dapat menekan tombol edit dan menghapus data mekanik admin dapat menekan tombol hapus.

Tampilan menu mekanik dapat dilihat pada Gambar 15 dan tampilan menu tambah data mekanik dapat dilihat pada Gambar 16.
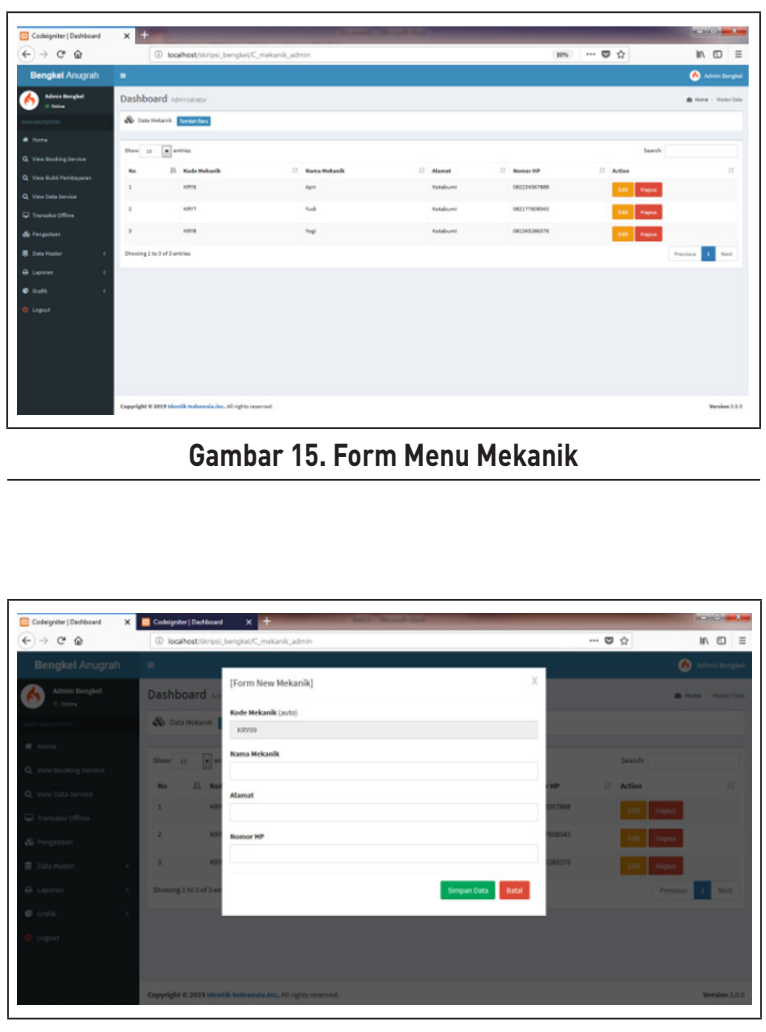

Gambar 16. Form Menu Tambah Data Mekanik 


\section{Menu Service}

Tampilan menu service digunakan untuk mengelola data jasa service pada bengkel Anugrah yang dapat diakses oleh admin. Admin dapat menekan tombol tambah baru untuk menambahkan data jasa service, admin dapat menekkan tombol edit untuk mengubah data jasa servise, dan menghapus data jasa service admin dapat menekan tombol hapus. Tampilan menu jasa sparepart dapat dilihat pada Gambar 17 dan tampilan menu tambah data dapat dilihat pada Gambar 18.

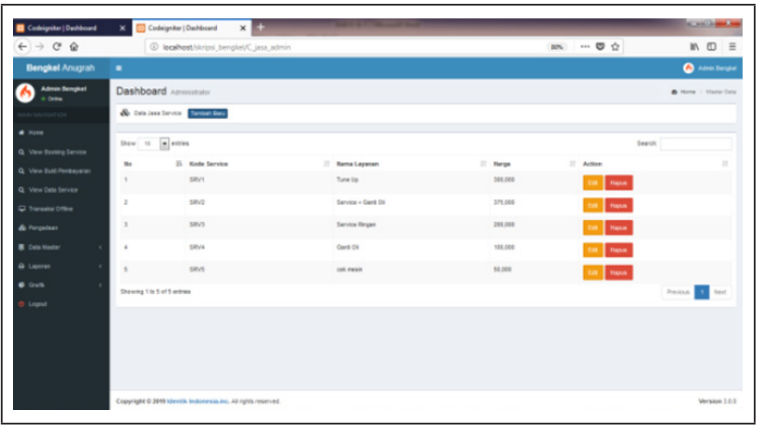

Gambar 17. Form Menu Jasa Service

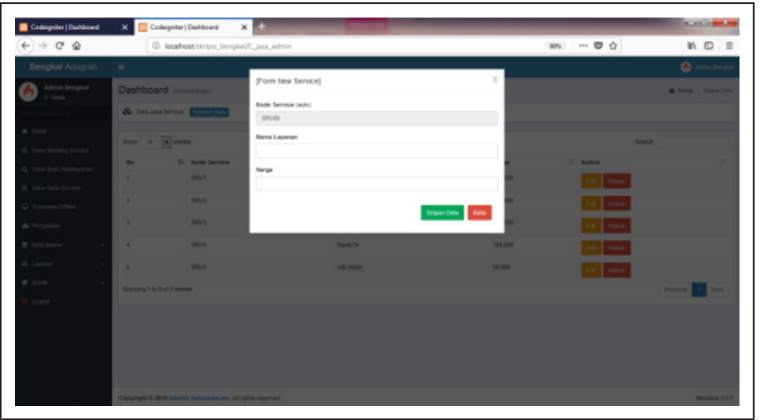

Gambar 18. Tampilan Menu Tambah Data

\section{Hak Akses Pemilik}

\section{Menu Login Pemilik}

Pemilik yang akan menggunakan aplikasi akan memasukkan username dan password yang telah diberikan, lalu menekan tombol login, sistem akan memproses username dan password tersebut. Bila inputan bernilai benar maka sistem akan mengarah ke halaman menu utama dan bila salah maka sistem akan memberikan peringatan bahwa username dan ppassword tidak benar. Tampilan menu login pemilik dapat dilihat pada Gambar 19.

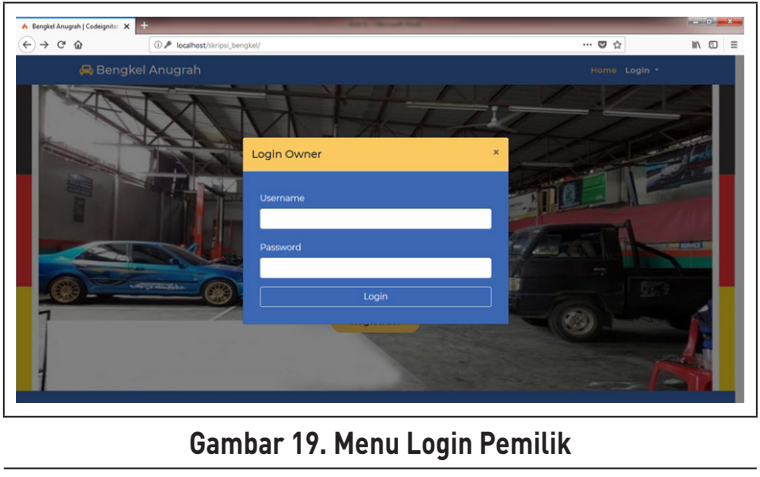

\section{Menu Grafik Penjualan Sparepart}

Menu grafik penjualan sparepart digunakan untuk melihat grafik penjualan dan grafik produk terlaris perbulan. Tampilan menu grafik dapat dilihat pada Gambar 20.

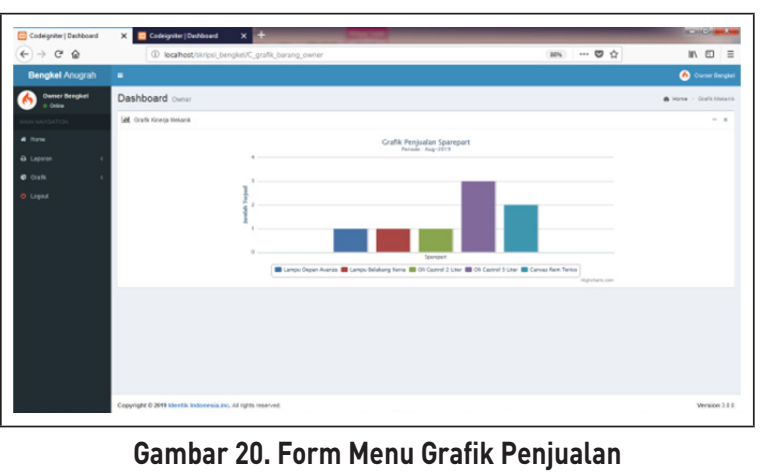

\section{Menu Grafik Kinerja Mekanik}

Menu grafik kinerja mekanik digunakan untuk melihat grafik kinerja mekanik, pengguna dapat memilih bulan dan menekan tombol view grafik untuk melihat grafik kinerja mekanik perbulan. Tampilan menu grafik produk terlaris dapat dilihat pada Gambar 21.

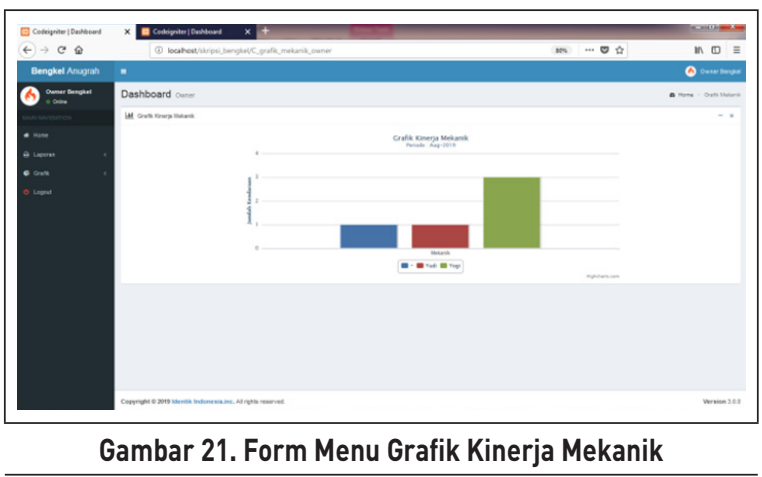

\section{Menu Grafik Service}

Menu grafik service digunakan untuk melihat grafik service pertahun pada bengkel anugrah yang dilakukan pemilik. Tampilan menu grafik service dapat dilihat pada Gambar 22. 


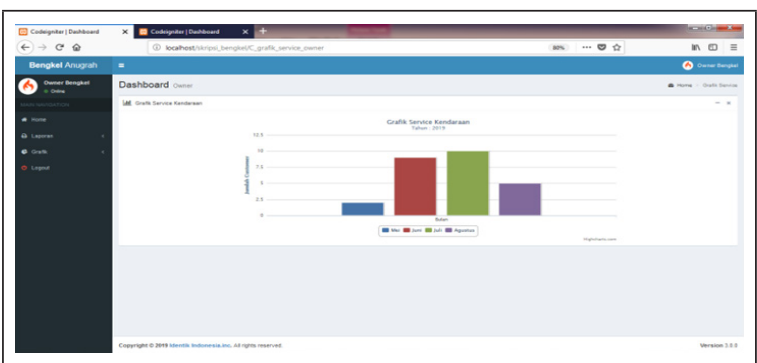

Gambar 22. Form Menu Grafik Service

\section{Menu Laporan}

Menu Laporan digunankan untuk melihat laporan service dan penjualan, laporan data booking service dan laporan data pelanggan. pengguna dapat menekan tombol cetak data customer untuk melihat dan mencetak laporan data customer. pengguna dapat menginputkan tanggal awal dan tanggal akhir yang diinginkan dan menekan tombol cetak untuk melihat dan mencetak laporan data booking service. Dan pengguna dapat menginputkan tanggal awal dan tanggal akhir yang diinginkan dan menekan tombol cetak untuk melihat dan mencetak laporan data service dan penjualan. Tampilan menu laporan dapat dilihat pada Gabar 23.



Gambar 23. Form Menu Laporan

\section{Form Laporan Data Service}

Form Laporan data service dan penjualan digunakan untuk melihat dan mencetak laporan data service. Tampilan data service dapat dilihat pada Gambar 24.

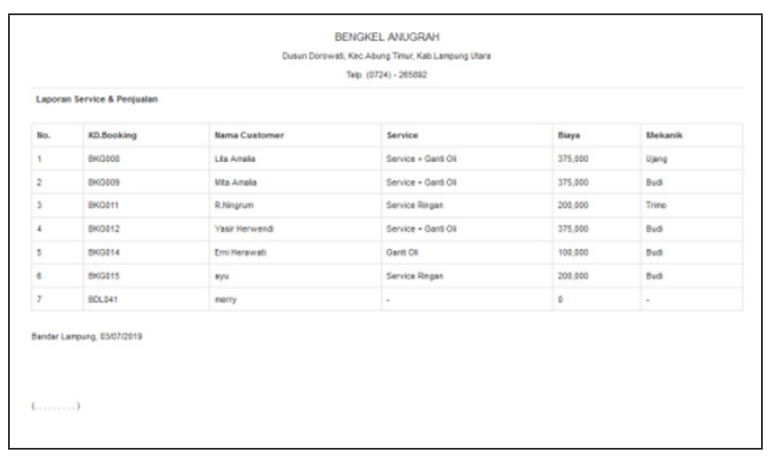

Gambar 24. Form Data Service dan Penjualan

\section{Form Laporan Data Pelanggan}

Form Laporan data pelanggan digunakan untuk melihat dan mencetak laporan data pelanggan yang dapat dilakukan oleh pemilik. Tampilan laporan data pelanggan dapat dilihat pada Gambar 25.

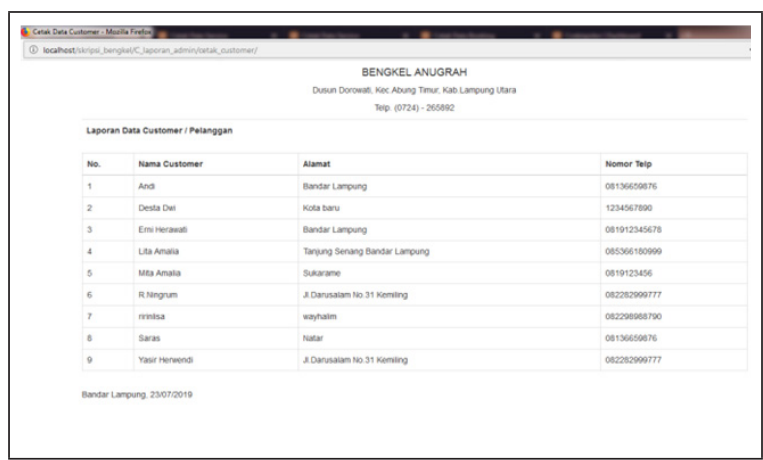

Gambar 25. Form Laporan Data Pelanggan

\section{Form Laporan Data Pengadaan}

Form Laporan data pengadaan digunakan utuk melihat dan mencetak laporan data pengadaan yang dapat dilakukan oleh pemilik. Tampilan laporan data booking dapat dilihat pada Gambar 26.

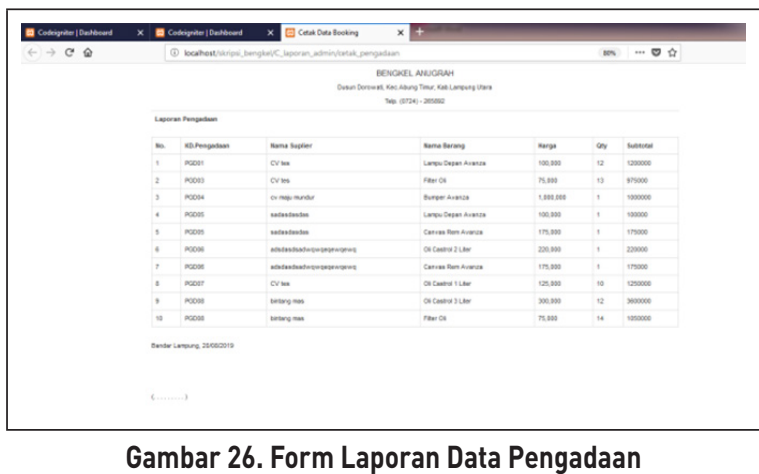

\section{Hasil Keseluruhan Pengujian ISO 25010}

Berikut hasil pengujian ISO 25010 secara keseluruhan pada aplikasi dapat dilihat pada tabel.

Tabel Hasil Keseluruhan Pengujian ISO 25010.

\begin{tabular}{|l|c|c|c|c|}
\hline \multicolumn{1}{|c|}{ Aspek } & Skor Aktual & Skor Ideal & \% Skor Aktual & Kriteria \\
\hline Functionality & 462 & 490 & 94.29 & Sangat Baik \\
\hline Reliability & 181 & 210 & 86.19 & Sangat Baik \\
\hline Efficiency & 133 & 140 & 95.00 & Sangat Baik \\
\hline Total & 776 & 840 & 92.38 & Sangat Baik \\
\hline \multicolumn{5}{|c}{ Gambar 27. Hasil Pengujian ISO 25010 } \\
\hline
\end{tabular}

Berdasarkan hasil pengujian ISO 25010 yang 
telah dilakukan dengan melibatkan 7 responden bahwa kesimpulan kualitas kelayakan perangkat lunak yang dihasilkan secara keseluruhan mempunyai skala "Sangat Baik" dan menurut sanusi (2012) dinilai layak untuk diterapkan.

\section{SIMPULAN}

Berdasarkan pembahasan dari hasil penelitian tentang Sistem Informasi Manajemen Bengkel, dapat diambil kesimpulan yaitu: Sistem ini dapat membuat laporan secara otomatis berdasarkan data yang tersimpan di database diharapkan dapat memudahkan pemilik bengkel untuk melihat laporan penjualannya. Sistem ini dapat menampilkan data service pelanggan yang telah diinputkan oleh admin. Sehingga memudahkan pelanggan dalam mengetahui rincian service yang telah dilakukan. Pengujian sistem menggunakan ISO 25010 dengan aspek fungsionality, efficiency, dan realibility. Hasil dari pengujian yang telah dilakukan dengan melibatkan 7 responden bahwa kesimpulan kualitas kelayakan perangkat lunak yang dihasilkan memiliki persentase keberhasilan dengan total rata-rata $92,38 \%$.

\section{PENGHARGAAN}

Pada kesempatan kali ini penulis ingin mengucapkan terimakasih kepada Bapak Arif Budiman dan Bapak Dedi Darwis sebagai Pembimbing dalam melaksanakan penelitian ini

\section{DAFTAR PUSTAKA}

Anhar. (2010). Pengenalann Sistem Informasi. Yogyakarta: Andi Offset.

Darwis, Dedi., Apriyanti, F.D., Susanto, E.R., (2019). Perancangan Sistem Infirmasi Akuntansi Pengeluaran Operasional Perusahaan. Jurnal Tekno Kompak, pp.1-6

Jogiyanto. (2010). Analisis dan Desain Sistem Informasi Pendekatan Terstruktur Teori dan Praktik Aplikasi Bisnis. Yogyakarta: Andi.

Kristanto. (2010). Perancangan Sistem Informasi dan Aplikasinya. Yogyakarta: Andi.

Kustiyahningsih. (2011). Cara Mudah Untuk Membangun Website Interakktif. Jakarta: Edisi Pertama.
McLeod, Jr, R., \& George. (2007). Sistem Informasi Manajemen. Yogyakarta: Graha Ilmu.

Nur, H. M. (2016). Sistem innformasi Service dan Penjualan Sparepart Motor Yamaha Pada PD Enggal Jaya Motor Cikarang Barat. SNIPTEK, 389-393.

Pangestu, \& Wiira, D. (2013). Sistem Informasi Manajemen. Jakarta: Andi.

Pasaribu, A.F., Darwis, Dedi., Irawan, Agus, Surahman, Ade.(2019) Sistem Informasi Geografis untuk Pencarian Lokasi Bengkel Mobil di Wilayah Kota Bandarlampung. Jurnal Tekno Kompak, pp. 1-6.

Pressman. (2012). Pendekatan Praktisi Rekayasa Perangkat Lunak. Yogyakarta: Andi.

Sanusi. (2012). Metodologi Penelitian Bisnis. Jakarta: Salemba Empat.

Setiadi, A., \& Alfiah, F. (2016). Sistem Penjualan Sparepart Toko AJM Motor Menggunakan CI Berbasis Arsitektur MVC. SIMETRIS, 575586.

Setiadi, N., \& Setiawan, R. (2016). Pengembangan Aplikasi Penjualan Sparepart Di Bengkel Anugrah Jaya Motor Berbasis Dekstoop. Jurnal Algoritma, 399-406.

Sutabri, T. (2012). Analisis Sistem Inormasi. Jakarta: Andi.

Sutanta, E. (2012). Basis Data Dalam Tinjauan Konseptual. Yogyakarta: Andi.

Wardani, A., \& Sari, R. (2017). Perancangan Sistem Informasi Penjualan Suku Cadang Mobil Berbasis Web (Studi Kasus : Kreasi Auto Parts). Ilmu Pengetahuan dan Teknologi Komputer, 142-252.

Welim, Y. Y., Wisjhnuadji, T. W., \& Firmansyah, R. (2015). Pengembangan Sistem Informasi Service Kendaraan Pada Bengkel KFMP. Jurnal Simetris, 17-26.

Wicaksono, Y. (2012). Konsep dan Aplikasi Sistem Pendukung Keputusan. Yogyakarta: Andi.

Yuliana, O. Y. (2000). Penggunaan Teknologi Internet Dalam Bisnis. Jurnal Akuntansi dan Keuangan, 36-52. 